\title{
Folic acid supplementation in pregnancy and implications in health and disease
}

\author{
Subit Barua*, Salomon Kuizon and Mohammed A Junaid
}

\begin{abstract}
Maternal exposure to dietary factors during pregnancy can influence embryonic development and may modulate the phenotype of offspring through epigenetic programming. Folate is critical for nucleotide synthesis, and preconceptional intake of dietary folic acid (FA) is credited with reduced incidences of neural tube defects in infants. While fortification of grains with FA resulted in a positive public-health outcome, concern has been raised for the need for further investigation of unintended consequences and potential health hazards arising from excessive FA intakes, especially following reports that FA may exert epigenetic effects. The objective of this article is to discuss the role of FA in human health and to review the benefits, concerns and epigenetic effects of maternal FA on the basis of recent findings that are important to design future studies.
\end{abstract}

Keywords: Folic acid, DNA methylation, Epigenetic, Imprinting, Prenatal nutrition, Neural tube defects, Autism

\section{Review}

\section{Introduction}

The emerging view of epidemiological studies indicates the importance of the intrauterine environment in early fetal development. With increased understanding of the fundamental mechanism, appropriate DNA methylation including the proper functioning of the epigenetic machinery is highlighted to be essential for embryogenesis and adult health [1-3]. Thus, FA has gained considerable attention because of its promising role in modulating diverse clinical conditions, whereas folate deficiency has been linked with a variety of disorders including birth defects and defects in the development of neural tube closure [4-6]. As stated by Hippocrates nearly 2,500 years ago: "Let food be thy medicine and medicine be thy food" the mandatory FA fortification appears to be a first modern attempt to design a strategy for using food for the prevention or treatment of developmental defects. However, this mandate has resulted in an increase in folate level in the serum to approximately $19 \mathrm{ng} / \mathrm{ml}$, which is above the normal range of the serum folate concentrations in humans i.e. 2.7-17 $\mathrm{ng} / \mathrm{ml}$ [7]. Epidemiological studies have shown that a significant number of women

\footnotetext{
* Correspondence: subitbarua@gmail.com Department of Developmental Biochemistry, New York State Institute for Basic Research in Developmental Disabilities, 1050 Forest Hill Road, Staten Island, NY 10314, USA
}

(C) 2014 Barua et al.; licensee BioMed Central Ltd. This is an Open Access article distributed under the terms of the Creative Commons Attribution License (http://creativecommons.org/licenses/by/4.0), which permits unrestricted use, distribution, and reproduction in any medium, provided the original work is properly credited. The Creative Commons Public Domain Dedication waiver (http://creativecommons.org/publicdomain/zero/1.0/) applies to the data made available in this article, unless otherwise stated. who took FA supplements during pregnancy exceeded the Institute of Medicine's recommended tolerable upper limit of $1,000 \mu \mathrm{g} /$ day. In addition, studies also reported consumption of $400 \mu \mathrm{g} /$ day of natural food folate plus FA-containing prenatal supplements resulted in supra-nutritional folate status with the greatest increases in pregnant women followed by lactating and non-pregnant women $[8,9]$. Concern has been raised if such exposure as a result of FA fortification will have any detrimental effects in the general population if not overtly benefit. This review summarizes the beneficial role of folate in human health, the metabolic pathway, epigenetic mechanism and potential concerns based on recent findings.

\section{Folic acid and neural tube defects}

Birth defects are one of the major burdens in the human public health with estimates from Centers for Disease Control and Prevention (CDC) approaching 1 in every 33 newborns in the US and accounting for more than $20 \%$ of all infant mortalities [10,11]. Neural tube defects (NTDs) are common complex multifactorial disorders in the neurulation of the brain and spinal cord that occurs between 21 and 28 days after conception in humans [12]. Worldwide depending on the ethnic grouping and geographical location, the prevalence has been reported to vary widely between 1 and 10 in every 1000 births or 
established pregnancies [13]. While we are beginning to understand the underlying etiologies, evidence gathered so far implicates both -genetic and non-genetic factors such as maternal nutritional status or maternal obesity in the onset of NTDs [14-16]. Over the years, numerous studies including community-based trials often suggested NTDs as vitamin deficiency disorders and have shown that the exogenous or periconceptional supplementation of maternal FA can reduce the risk of NTDs in offspring [17]. Indeed, research spanning decades suggests folate deficiency as a risk factor of NTDs; however the involvement of whole methylation metabolism has also been linked with the etiology of NTDs $[16,18,19]$. Arguing against the maternal folate deficiency model alone, some studies also reported normal concentrations of folate in the mothers of human fetuses with NTDs. Supporting this, studies in cultured rat embryos or FA deficient mice were reported not to be affected by NTDs as a result of FA deficiency [20-24]. In contrast, studies also reported that exogenous FA and thymidine in the homozygous splotch (Pax3) mouse embryos prevented NTDs and corrected biosynthetic defects [25]. Therefore, no consensus has been reached based on the published data to date. However, as FA deficiency may be a risk factor for NTDs additional studies will be required to determine the mechanistic role of the FA pathway in the onset of neural tube defects.

\section{History and impact of folic acid on public health}

A possible relationship between apparent folate deficiency and increased incidence of prematurity was suggested as early as 1944 by Callender [26]. This was later confirmed by Gatenby and Lillie [27], and in 1960s, Richard Smithells and Elizabeth Hibbard hypothesized that the under nutrition or impaired folate status could be an important factor in the origin of NTD based on significant observations, that women who had given birth to the children with birth defects i.e. anencephaly and spinabifida have an altered formiminoglutamic acid compared to the women with unaffected children [28]. To test this hypothesis Smithells and his group conducted an intervention trial with supplementation of a multivitamin containing diet with FA $0.36 \mathrm{mg} /$ day during the periconceptional period to the participating women who previously had infants with NTD. Incontrast, women who were already pregnant without vitamin supplementation were considered as controls. In the1980's, they published the results of this multi-center intervention study that revealed about $83-91 \%$ reduction in NTD recurrence in supplemented women compared to that of unsupplemented women [29-32]. These results first highlighted that multivitamin or FA supplementation may play a significant role in gestation and may reduce the recurrence of NTD. Later in 1991, after a randomized control trial (RCT) conducted at 33 centers in seven countries, the British Medical Research Council suggested, for women with a previous history of NTD-affected -pregnancies, the daily supplementation of 400 micrograms of FA is effective in preventing the recurrence of NTDs by 70\% [33]. This was further supported by the results of a - RCT conducted in Hungary in 1992 that reported a daily intake of $0.8 \mathrm{mg}$ of FA during the periconceptional period significantly reduced the incidence of a first occurrence of NTD [34]. In 1991, the CDC recommended a daily intake of $4000 \mu \mathrm{g}$ of FA before and throughout the period of pregnancy for women with prior history of NTD-affected pregnancy [35]. Later in 1998, based on the evidence and recommendation from the wider medical community, the U.S. Public Health Service and Food and Drug Administration recommended mandatory fortifications of FA in flour and grains to prevent NTD and birth defects [36]. In 2007, the Canadian recommendations also included obesity (BMI $>35)$ as a health risk, and recommended "the higher dose FA strategy ( $5 \mathrm{mg}$ )" in patients with a history of poor compliance with medications and additional lifestyle issues of variable diet, no consistent birth control, alcohol, tobacco, and recreational non-prescription drugs use. Furthermore, to prevent the occurrence of NTDs in epileptic and diabetic mothers the recommendation is to take a higher dose of FA, 4-5 mg/day [37-39].

\section{Folate metabolism}

FA is central to folate-requiring one-carbon metabolism which play key roles in numerous cellular reactions. These involve amino acid metabolism, biosynthesis of purine and pyrimidine; (the building blocks for DNA and RNA synthesis), and formation of primary methylating agent $\mathrm{S}$-adenosyl-methionine (SAM), which is the universal methyl donor for DNA, histones, proteins and lipids [10]. Mechanistically, the transport of transmembrane folate is facilitated by both receptors and specific carriers active across cell membranes [40]. Under normal circumstances, natural dietary folate is absorbed in the intestine and/or liver and metabolized primarily to 5-methyl tetrahydrofolate (5-methylTHF) and subsequently gets polyglutamated for cellular retention (Figure 1). However, FA consumed in fortified foods/supplements is reduced primarly to dihydrofolate by the enzyme dihydrofolate reductase in the liver and finally converted to the tetrahydrofolate (THF), the substrate for polyglutamate synthetase. The polyglutamyl form of tetrahydrofolate (THF) formed either from FA or normal dietary folate is the central folate acceptor molecule in the one-carbon cycle. Next, THF is converted to 5,10-methyleneTHF by vitamin B6 dependent serine hydroxymethyltransferase and then reduced irreversibly to 


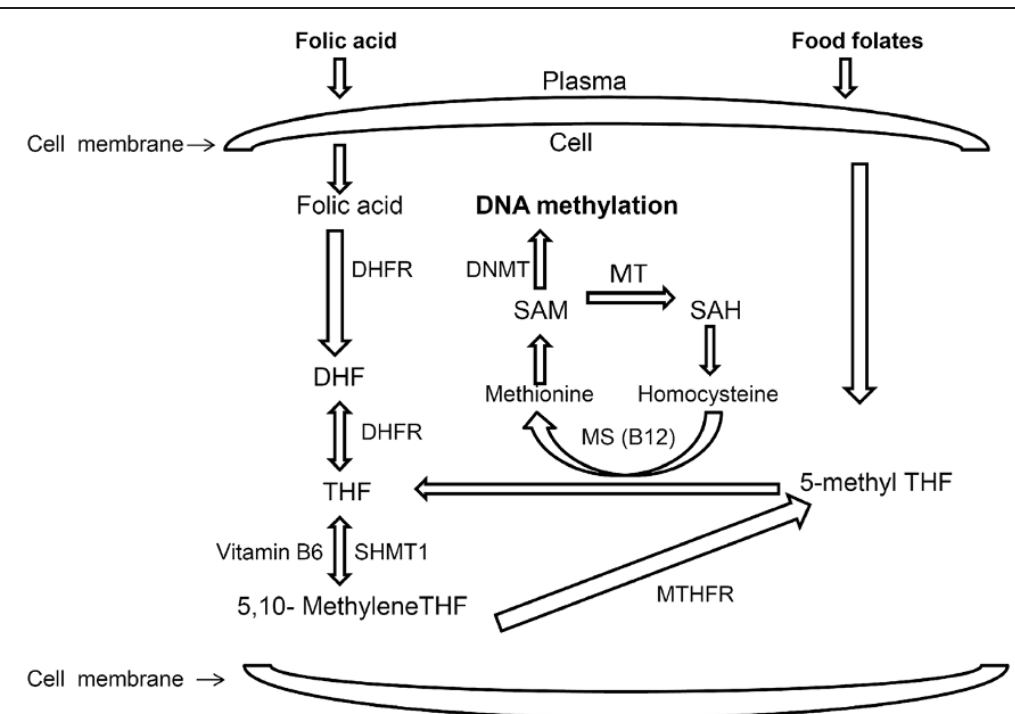

Figure 1 Summary of folate metabolism (simplified). The schematic diagram shows that after entry of synthetic FA or natural dietary folates through receptors/carriers in cell membrane, the intracellular folate/ FA pass through series of biochemical reactions, and alter DNA methylation. Abbreviations: DHFR, dihydrofolate reductase; DHF, dihydrofolate; THF, tetrahydrofolate; SHMT, serine-hydroxymethyltransferase; 5,10-methenyl- THF, 5,10-methenyl-tetrahydrofolate; MTHFR, 5,10-methylenetetrahydrofolate reductase; 5-methyl THF, 5-methyltetrahydrofolate; MS, methionine synthase; B12, vitamin B-12; SAM, S-adenosylmethionine; SAH, S-adenosylhomocysteine; DNMT, DNA methyltransferase; MT, methyltransferases.

5-methylTHF by methylenetetrahydrofolate reductase (MTHFR). 5-Methyl-THF acts as a primary methyl donor for the remethylation of homocysteine to methionine. Methonine is a key substrate for S-adenosylmethionine (SAM) which plays a central role in methylation reactions catalyzed by DNA methyltransferases (DNMTs) forming 5-methylcytosine [41-43]. Thus, the entire FA metabolism is modulated by several folate coenzymes. Mechanistically, the central role of this coenzyme is to modulate the metabolic pathway by accepting or donating one-carbon units [44]. Key genes in this pathway that are involved in transferring the methyl group to homocysteine, and have been most extensively studied include methylenetetrahydrofolate reductase (MTHFR), methionine synthase reductase (MTRR), reduced folate carrier (RFC), along with vitamin B12- dependent methionine synthase (MTR) [45]. Intriguingly, the etiology of NTDs has long been genetically associated with the dysregulation of the major folate pathway or methionine synthase genes, and single-nucleotide polymorphisms (SNPs) such as $677 \mathrm{C}>\mathrm{T}$ in the MTHFR gene in humans $[25,46]$. Thus, further studies on FA induced methylation and detailed analysis of the folate pathway and its role in mammalian neural tube closure could give us more insights in coming years.

\section{Implications of FA in epigenetic regulation}

The possible impact of nutritional supplements, for example FA, on the mammalian genome can have long lasting effects in human health without any underlying genetic change. The availability of many dietary components involved in one-carbon metabolism including vitamin B6, choline, betanine, methionine, vitamin B12 and folate can result in alterations in the DNA methylation and histone modification. Mechanistically, the modulation of methylation patterns depends on the level of two metabolites of one-carbon metabolism: $S$-adenosylmethionine (SAM), a methyl donor and $S$-adenosylhomocysteine (SAH), a product inhibitor of methyltranferases [47-49]. Thus, nutrient epigenetic factors such as FA, a cofactor in one-carbon metabolism during gestation can affect the fetal programming and may modulate the genome-wide methylation pattern of DNA and cause dysregulation in the expression of genes [50]. The epigenetic impact of FA along with other onecarbon metabolites is best studied in the agouti mouse $\left(A^{v y}\right)$ experiment that has shown that the dietary methyl donors, including FA, has no affect on the $A^{v y}$ methylation in the mother but clearly affected the $A^{v y}$ methylation and phenotype of developing offspring [51]. Similar to the animal study, a study in young children from mothers having periconceptional FA of $400 \mu \mathrm{g}$ per day was shown to have enrichment in the methylation of maternally imprinted insulin-like growth factor 2 gene (IGF2) compared to those with no periconceptional maternal FA [52]. In addition, several epidemiologic and molecular evidences also link folate supplementation and epigenetic alteration by DNA methylation with neural growth and recovery, including the activation of folate receptor (Folr1), in spinal cord regeneration $[53,54]$. In an attempt to understand the FA induced epigenetic mechanism to rescue neural tube closure, a recent study in Splotch embryos ( $\mathrm{Sp}-/-)$ has also shown that 
maternal intake of folate prior to conception decreases the H3K27 methylation marks and remodels the chromatin on Hes1 and Neurog2 promoters, genes that are essential for neural tube development [55]. Recently, our study has shown that FA supplementation dysregulates expressions of several genes including FMR1 in lymphoblastoid cells [56], and a follow up study in a mouse model has also identified widespread alteration in the methylation pattern of the brain epigenome in offspring from high maternal FA during gestation [57]. The alterations in the methylation pattern were exhibited both in $\mathrm{CpG}$ and non-CpG regions resulting in differences in the expression of several key developmental and imprinted genes. In addition, we also found that the methylation and expression of several genes are altered in a gender-specific manner. Thus, it is clear that folate plays a key role in epigenetic regulation of fetal developmental programming. In the future, more studies on the role of folate deficiency or over supplementation on epigenetic alterations will establish causality of the amount of FA and DNA methylation in diseases.

\section{Folate intake and concern about potential adverse effect}

The clinical significance of the chronic or high intake of FA is not well established. Post fortification epidemiological studies have reported an increase of approximately twice the amount in the intake of FA than previously projected. Concern has been raised regarding the potential health effects, since in addition to the fortified products there is prevalence of using widespread supplementation including over-the counter prenatal vitamins as well as energy drinks which are substantially enriched with various vitamins [58,59]. Recently, our study in the mouse model has found that ten-fold increase in maternal FA supplementation during gestation altered the expression of several genes in the frontal cortex of day old pups [60]. Moreover, continuation of such higher amounts of FA throughout the post-weaning period exhibited alterations in behaviors compared to offspring from mothers having lower doses of gestational FA supplementation. Mechanistically, such changes of behavioral outcomes may possibly result from alterations of gene expression as a result of aberrant methylation.

Intriguingly, results from several studies also suggested that folate supplementation can induce aberrant patterns of DNA methylation, and mechanistically may play a dual role in carcinogenesis. FA supplementation may prevent the early lesions, or potentially harm by enhancing the progression of established preneoplastic lesions [61]. Studies in rodent models -have shown that supplementation of FA promotes the progression of mammary tumor, and supporting this view a study in a genetically engineered mouse model of a human cancer has shown that FA deficiency during the peri-gestational period protects or decreases medulloblastoma formation
$[62,63]$. However, a meta-analysis of data conducted on 50,000 individuals to assess the effects of FA found that FA supplementation does not substantially increase or decrease incidence of site-specific cancer during the first 5 years of treatment $(\mathrm{RR}=1.06,95 \% \mathrm{CI} 0.99-1.13)$ in comparison to placebo [64]. Moreover, a study from children participating in the Northern California Childhood Leukemia Study (NCCLS) further revealed no significant association of folate concentration at birth with childhood acute myeloid leukemia (Additional file 1: Table S1). In contrast, several RCT and meta-anlayis have reported that prenatal multivitamins containing FA -are associated with a significant protective effect on pediatric cancers: leukemia, pediatric brain tumors and neuroblastoma [65], (Additional file 1: Table S1). In addition, recent ecological studies provided support for a decrease in Wilms tumour, neuroblastoma, primitive neuroectodermal tumours and ependymomas after Canadian and United States FA fortification [66,67], (Additional file 1: Table S1).

Although controversial, over-supplementation is also reported to be involved in certain chronic disease and found not to reduce cardiovascular disease $[68,69]$. In addition, acute folate intake is also found to result in significant down-regulation of folate transporters in kidney, and thus dysregulated the renal folate uptake process [70]. Moreover, several RCT and observational studies suggested that maternal intake of multivitamins including FA during pregnancy may modulate pregnancy related outcomes [71-75] including developmental outcome of offspring (Additional file 1: Table S1).

The causal link between the maternal FA supplementation and the development of childhood asthma has been of interest as asthma is considered to be an interaction of both genetic and environmental risk factors, and concern has arisen as epidemiological studies have also shown that increased folate in pregnancy may influence poor respiratory health in children [76,77]. Several studies, including RCT and observational studies were conducted to reveal such associations, however conflicting results were found in these studies. While some studies found positive association between FA exposure and increase in risk of childhood asthma, other studies found no such association (Additional file 1: Table S1). In addition, studies in humans, also reported to have found higher blood folate concentration of unmetabolized FA and naturally occurring folates [78].

To gain a better understanding if maternal supplementation of FA modulates pregnancy related outcomes, much focus has been given to reveal the role of FA supplementation in the increased incidence of dizygotic twining. This followed after the report of a Swedish study suggested a possible association of FA supplementation with the increase in the twining rate [79]. A meta- 
analysis using the Food Standards Australia New Zealand (FSANZ) framework by Muggli et al. [80] has suggested that the hypothesis of the increase in dizygotic twins is still to be demonstrated $(\mathrm{OR}=1.26,95 \% \mathrm{CI}$ 0.91-1.73 for pre-conceptional supplementation and dizygotic twins; $\mathrm{OR}=1.02$, 95\% CI $0.85-1.24$ for overall twins), and, if true, it would only cause a very limited increase. However, Berry et al. reported that the association of FA with an increase in dizygotic twining as reported by the Swedish study has probably led to false findings based on the reported $40 \%$ misclassification of the use of in vitro fertilization [81]. This was further supported by a Norwegian study that found no evidence for an association between preconceptional folate supplements and twinning after exclusion of known in vitro fertilization pregnancies, and accounting for underreporting of both in vitro fertilization pregnancies and folate use [82].

Thus it is clear that FA intake during pregnancy and during daily life plays a significant role in modulating gene expression and disease related outcome. Considering the important role of FA in several cellular process, including epigenetic modulation and reducing the incidence of NTDs (Additional file 1: Table S1), the dose, timing (pre-conceptional/peri-conceptional/in-pregnancy), and source of folate intervention during pregnancy and throughout the life time may be critical. In the future, more clinical and basic studies to decipher the link between over supplementation and normal development will help us to understand the discordances between benefit and possible harm.

Maternal folate intake and health outcomes in children - a brief systemic review of recent cohorts study

For a better understanding of the effect of maternal FA, we systematically reviewed recent published literature (2011-2014) in order to assess the outcome of maternal FA supplementation on the health of newborn infants [83-134] (Additional file 1: Table S1). While results of several cohort and observational studies in USA, Canada, Chile, Australia, several countries in Europe and Asia have reported the clinical significance of FA supplementation, the direction of the beneficial effect was not in favorable terms in all the cases. Therefore, several countries have mandatory regulated FA fortifications, and despite its efficacy there is no universal agreement based on the published data to date [135]. The concern regarding the appropriate dose and potential side effects are still a matter of debate $[16,136]$. As maternal FA can induce potential epigenetic effects on the genome of the offspring which may vary with the metabolic ability of individual race, sex, geographical locations or interactions with other nutrients, one possible reason of inconsistency between studies may be due to differences in the design of the study. In the future there is definitely a need of global collaboration to accumulate scientific evidence from a clinical perspective, and to interpret these intervention studies and potential effect in large cohorts.

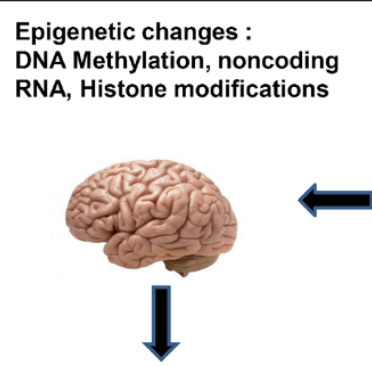

Altered Gene expression
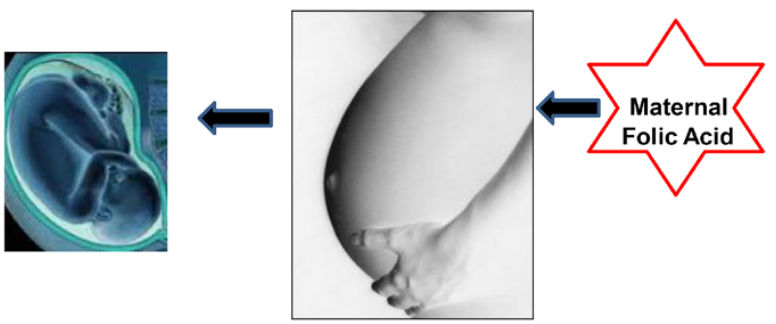
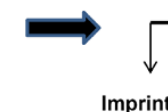
Imprinted
genes?
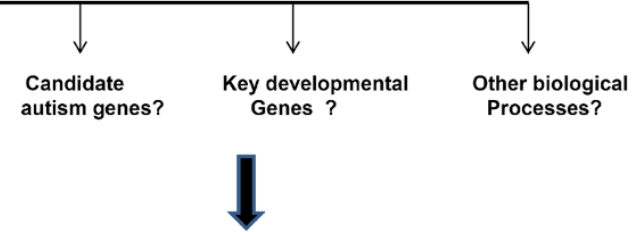

Developmental outcomes?

Figure 2 A representative integrative model of possible epigenetic influence on pregnancy outcomes. Maternal intake of FA may result in epigenetic modulation in the offspring brain methylome with overall or site specific alterations of methylation in genomic DNA, non-coding RNA and histone modifications. These effects may alter gene expression of several imprinted, candidate autism susceptibility and key developmental genes. Such changes may impact other biological processes, and associate with the overall developmental outcome. Scientific artwork adapted from $[137,138]$ 


\section{Conclusion}

The clinical application of FA supplementation/intake to prevent NTDs has been well proven for the last 20-25 years (Additional file 1: Table S1). However considering the concern with the level of folate concentration following post-fortifications, it is of interest to explore if FA exposure in significant sections of the population is influencing other normal biological processes, such as the brain's development (Figure 2). Determining the level and distribution of the methylation profile of the brain epigenome may reveal the mechanism and downstream consequences of various neuropsychiatric and imprinted disorders including autism. Moreover as the level of folate status can influence methylation, in the future more studies are needed to explore the systemic differences in the DNA methylation profile in relation to timing and dose between different populations and between genders. Studies and careful monitoring of the consequences of FA intake in global perspectives will help clinicians to determine a proper therapeutic strategy and the best preventive measures to improve the overall public health, moreover to precisely differentiate the evaluation of this vitamin in nutrition, in fortification and in supplementation.

\section{Additional file}

Additional file 1: Table S1. Studies of maternal folate intake and health outcomes in children.

\begin{abstract}
Abbreviations
FA: Folic acid; NTD: Neural tube defect; CDC: Centers for disease control and prevention; RCT: Randomized control trial; SAM: S-adenosyl- methionine; $\mathrm{SAH}$ : S-adenosylhomocysteine; DNMTs: DNA methyltransferase; 5-methylTHF: 5-methyl tetrahydrofolate; THF: Tetrahydrofolate; MTHFR: Methylenetetrahydrofolate reductase; MTRR: Methionine synthase reductase; MTR: Methionine synthase; RFC: Reduced folate carrier; SNPS: Single-nucleotide polymorphisms; IGF2: Insulin-like growth factor 2 gene; BMI: Body mass index; TRoCA: Tabriz registry of congenital anomalies; LiST: Live saved tool; PTB: Preterm birth; SGA-W: Small-for-gestational age for weight; SGA-H: Small-for-gestational age for height; ALL: Acute lymphoblastic leukemia; AML: Acute myeloid leukemia; CBT: Childhood brain tumors.
\end{abstract}

\section{Competing interests}

The authors declare that they have no competing interests.

\section{Authors' contributions}

SB conceptualized the content, and wrote the manuscript; SK assisted with the revision of manuscript; MAJ conceptualized the content and critically revised the manuscript. All authors read and approved the final manuscript.

\section{Acknowledgements}

Financial support from the March of Dimes Research Foundation (12-FY12-170) and the New York State Office for People With Developmental Disabilities is gratefully acknowledged.

Received: 5 April 2014 Accepted: 11 August 2014 Published: 19 August 2014

\section{References}

1. Smith ZD, Chan MM, Mikkelsen TS, Gu H, Gnirke A, Regev A, Meissner A: $A$ unique regulatory phase of DNA methylation in the early mammalian embryo. Nature 2012, 484:339-344.
2. Jaenisch R, Bird A: Epigenetic regulation of gene expression: how the genome integrates intrinsic and environmental signals. Nat Genet 2003, 33(Suppl):245-254.

3. Gabory A, Attig L, Junien C: Developmental programming and epigenetics. Am J Clin Nutr 2011, 94:1943S-1952S.

4. Smithells RW, Sheppard S, Schorah CJ: Vitamin dificiencies and neural tube defects. Arch Dis Child 1976, 51:944-950.

5. Li D, Rozen R: Maternal folate deficiency affects proliferation, but not apoptosis, in embryonic mouse heart. J Nutr 2006, 136:1774-1778.

6. Blom HJ, Shaw GM, Den Heijer M, Finnell RH: Neural tube defects and folate: case far from closed. Nat Rev Neurosci 2006, 7:724-731.

7. Rosati $\mathrm{R}, \mathrm{Ma} \mathrm{H}$, Cabelof DC: Folate and colorectal cancer in rodents: a model of DNA repair deficiency. J Oncol 2012, 2012:105949.

8. Hoyo C, Murtha AP, Schildkraut JM, Forman MR, Calingaert B, Demark-Wahnefried W, Kurtzberg J, Jirtle RL, Murphy SK: Folic acid supplementation before and during pregnancy in the Newborn Epigenetics STudy (NEST). BMC Public Health 2011, 11:46

9. West AA, Yan J, Perry CA, Jiang X, Malysheva OV, Caudill MA: Folate-status response to a controlled folate intake in nonpregnant, pregnant, and lactating women. Am J Clin Nutr 2012, 96:789-800.

10. Wallingford JB, Niswander LA, Shaw GM, Finnell RH: The continuing challenge of understanding, preventing, and treating neural tube defects. Science 2013, 339:1222002.

11. CDC: 2014. http://www.cdc.gov/ncbddd/birthdefects/data.html. Ref Type: Report.

12. Pitkin RM: Folate and neural tube defects. Am J Clin Nutr 2007, 85:285S-288S.

13. Au KS, Ashley-Koch A, Northrup H: Epidemiologic and genetic aspects of spina bifida and other neural tube defects. Dev Disabil Res Rev 2010, 16:6-15.

14. Northrup H, Volcik KA: Spina bifida and other neural tube defects. Curr Probl Pediatr 2000, 30:313-332.

15. Frey L, Hauser WA: Epidemiology of neural tube defects. Epilepsia 2003 44(Suppl 3):4-13.

16. Imbard A, Benoist JF, Blom HJ: Neural tube defects, folic acid and methylation. Int J Environ Res Public Health 2013, 10:4352-4389.

17. De Regil LM, Fernandez-Gaxiola AC, Dowswell T, Pena-Rosas JP: Effects and safety of periconceptional folate supplementation for preventing birth defects. Cochrane Database Syst Rev 2010, CD007950.

18. Vandevijvere S, Amsalkhir S, Van Oyen H, Moreno-Reyes R: Determinants of folate status in pregnant women: results from a national cross-sectional survey in Belgium. Eur J Clin Nutr 2012, 66:1172-1177.

19. Blom HJ: Folic acid, methylation and neural tube closure in humans. Birth Defects Res A Clin Mol Teratol 2009, 85:295-302.

20. Kirke PN, Molloy AM, Daly LE, Burke H, Weir DG, Scott JM: Maternal plasma folate and vitamin B12 are independent risk factors for neural tube defects. Q J Med 1993, 86:703-708.

21. Scott JM: Folate and vitamin B12. Proc Nutr Soc 1999, 58:441-448

22. Scott JM, Weir DG, Molloy A, McPartlin J, Daly L, Kirke P: Folic acid metabolism and mechanisms of neural tube defects. Ciba Found Symp 1994, 181:180-187.

23. Heid MK, Bills ND, Hinrichs SH, Clifford AJ: Folate deficiency alone does not produce neural tube defects in mice. J Nutr 1992, 122:888-894.

24. Burgoon JM, Selhub J, Nadeau M, Sadler TW: Investigation of the effects of folate deficiency on embryonic development through the establishment of a folate deficient mouse model. Teratology 2002, 65:219-227.

25. Fleming A, Copp AJ: Embryonic folate metabolism and mouse neural tube defects. Science 1998, 280:2107-2109.

26. Callender STE: A critical review of pernicious anaemia of pregnancy. Q J Med 1944, 13:75-105.

27. Gatenby PB, Lillie EW: Clinical analysis of 100 cases of severe megaloblastic anaemia of pregnancy. Br Med J 1960, 2:1111-1114

28. Hibbard ED, Smithells RW: Folic acid metabolism and human embryopathy. Lancet 1965, 285:1254.

29. Smithells RW, Sheppard S, Wild J, Schorah CJ: Prevention of neural tube defect recurrences in Yorkshire: final report. Lancet 1989, 2:498-499.

30. Nevin NC, Seller MJ: Prevention of neural-tube-defect recurrences. Lancet 1990, 335:178-179.

31. Smithells RW, Sheppard S, Schorah CJ, Seller MJ, Nevin NC, Harris R, Read AP, Fielding DW: Possible prevention of neural-tube defects by periconceptional vitamin supplementation. Lancet 1980, 315:339-340.

32. Wald NJ: Commentary: a brief history of folic acid in the prevention of neural tube defects. Int J Epidemiol 2011, 40:1154-1156. 
33. MRC Vitamin Study Research Group: Prevention of neural tube defects: results of the Medical Research Council Vitamin Study. Lancet 1991, 338:131-137.

34. Czeizel $A E$, Dudas I: Prevention of the first occurrence of neural-tube defects by periconceptional vitamin supplementation. N Engl J Med 1992, 327:1832-1835.

35. Centers for Disease Control (CDC): Use of folic acid for prevention of spina bifida and other neural tube defects-1983-1991. MMWR Morb Mortal Wkly Rep 1991, 40:513-516.

36. Crandall BF, Corson VL, Evans MI, Goldberg JD, Knight G, Salafsky IS: American College of Medical Genetics statement on folic acid: fortification and supplementation. Am J Med Genet 1998, 78:381.

37. Wilson RD, Johnson JA, Wyatt P, Allen V, Gagnon A, Langlois S, Blight C, Audibert F, Desilets V, Brock JA, Koren G, Goh YI, Nguyen P, Kapur B: Pre-conceptional vitamin/folic acid supplementation 2007: the use of folic acid in combination with a multivitamin supplement for the prevention of neural tube defects and other congenital anomalies. J Obstet Gynaecol Can 2007, 29:1003-1026.

38. Kennedy D, Koren G: Identifying women who might benefit from higher doses of folic acid in pregnancy. Can Fam Physician 2012, 58:394-397.

39. Wald NJ, Law MR, Morris JK, Wald DS: Quantifying the effect of folic acid Lancet 2001, 358:2069-2073.

40. Fowler B: The folate cycle and disease in humans. Kidney Int Supp/ 2001, 78:S221-S229

41. Crider KS, Yang TP, Berry RJ, Bailey LB: Folate and DNA methylation: a review of molecular mechanisms and the evidence for folate's role. Adv Nutr 2012, 3:21-38

42. Hubner RA, Houlston RS: Folate and colorectal cancer prevention. Br J Cancer 2009, 100:233-239.

43. Liu JJ, Ward RL: Folate and one-carbon metabolism and its impact on aberrant DNA methylation in cancer. Adv Genet 2010, 71:79-121.

44. Stanger O: Physiology of folic acid in health and disease. Curr Drug Metab 2002, 3:211-223

45. Zhang T, Lou J, Zhong R, Wu J, Zou L, Sun Y, Lu X, Liu L, Miao X, Xiong G: Genetic variants in the folate pathway and the risk of neural tube defects: a meta-analysis of the published literature. PLoS One 2013, 8:e59570.

46. Molloy AM, Brody LC, Mills JL, Scott JM, Kirke PN: The search for genetic polymorphisms in the homocysteine/folate pathway that contribute to the etiology of human neural tube defects. Birth Defects Res A Clin Mol Teratol 2009, 85:285-294.

47. Hoffman DR, Marion DW, Cornatzer WE, Duerre JA: S-Adenosylmethionine and S-adenosylhomocystein metabolism in isolated rat liver. Effects of L-methionine, L-homocystein, and adenosine. J Biol Chem 1980, 255:10822-10827.

48. James SJ, Melnyk S, Pogribna M, Pogribny IP, Caudill MA: Elevation in S-adenosylhomocysteine and DNA hypomethylation: potential epigenetic mechanism for homocysteine-related pathology. J Nutr 2002 132:2361S-2366S.

49. Yi P, Melnyk S, Pogribna M, Pogribny IP, Hine RJ, James SJ: Increase in plasma homocysteine associated with parallel increases in plasma S-adenosylhomocysteine and lymphocyte DNA hypomethylation. J Biol Chem 2000, 275:29318-29323.

50. Kim KC, Friso S, Choi SW: DNA methylation, an epigenetic mechanism connecting folate to healthy embryonic development and aging. J Nutr Biochem 2009, 20:917-926.

51. Waterland RA, Travisano M, Tahiliani KG: Diet-induced hypermethylation at agouti viable yellow is not inherited transgenerationally through the female. FASEB J 2007, 21:3380-3385.

52. Steegers-Theunissen RP, Obermann-Borst SA, Kremer D, Lindemans J, Siebel C, Steegers EA, Slagboom PE, Heijmans BT: Periconceptional maternal folic acid use of 400 microg per day is related to increased methylation of the IGF2 gene in the very young child. PLoS One 2009, 4:e7845.

53. Meethal SV, Hogan KJ, Mayanil CS, Iskandar BJ: Folate and epigenetic mechanisms in neural tube development and defects. Childs Nerv Syst 2013, 29:1427-1433.

54. Iskandar BJ, Rizk E, Meier B, Hariharan N, Bottiglieri T, Finnell RH, Jarrard DF, Banerjee RV, Skene JH, Nelson A, Patel N, Gherasim C, Simon K, Cook TD, Hogan $\mathrm{KJ}$ : Folate regulation of axonal regeneration in the rodent central nervous system through DNA methylation. J Clin Invest 2010, 120:1603-1616.
55. Ichi S, Costa FF, Bischof JM, Nakazaki H, Shen YW, Boshnjaku V, Sharma S, Mania-Farnell B, McLone DG, Tomita T, Soares MB, Mayanil CS: Folic acid remodels chromatin on Hes 1 and Neurog 2 promoters during caudal neural tube development. J Biol Chem 2010, 285:36922-36932.

56. Junaid MA, Kuizon S, Cardona J, Azher T, Murakami N, Pullarkat RK, Brown WT: Folic acid supplementation dysregulates gene expression in lymphoblastoid cells-implications in nutrition. Biochem Biophys Res Commun 2011, 412:688-692.

57. Barua S, Kuizon S, Chadman KK, Flory MJ, Brown WT, Junaid MA: Single-base resolution of mouse offspring brain methylome reveals epigenome modifications caused by gestational folic acid. Epigenetics Chromatin 2014, 7:3.

58. Choumenkovitch SF, Selhub J, Wilson PW, Rader Jl, Rosenberg $\| H_{\text {, Jacques }}$ PF: Folic acid intake from fortification in United States exceeds predictions. J Nutr 2002, 132:2792-2798.

59. Ly A, Lee H, Chen J, Sie KK, Renlund R, Medline A, Sohn KJ, Croxford R, Thompson LU, Kim Yl: Effect of maternal and postweaning folic acid supplementation on mammary tumor risk in the offspring. Cancer Res 2011, 71:988-997.

60. Barua S, Chadman KK, Kuizon S, Buenaventura D, Stapley NW, Ruocco F, Begum U, Guariglia SR, Brown WT, Junaid MA: Increasing Maternal or Post-Weaning Folic Acid Alters Gene Expression and Moderately Changes Behavior in the Offspring. PLoS One 2014, 9:e101674.

61. Ulrich CM, Potter JD: Folate supplementation: too much of a good thing? Cancer Epidemiol Biomarkers Prev 2006, 15:189-193.

62. Deghan MS, Ishiguro L, Sohn KJ, Medline A, Renlund R, Croxford R, Kim Yl: Folic Acid supplementation promotes mammary tumor progression in a rat model. PLOS One 2014, 9:e84635.

63. Been RA, Ross JA, Nagel CW, Hooten AJ, Langer EK, DeCoursin KJ, Marek CA, Janik CL, Linden MA, Reed RC, Schutten MM, Largaespada DA, Johnson KJ: Perigestational dietary folic acid deficiency protects against medulloblastoma formation in a mouse model of nevoid basal cell carcinoma syndrome. Nutr Cancer 2013, 65:857-865.

64. Vollset SE, Clarke R, Lewington S, Ebbing M, Halsey J, Lonn E, Armitage J, Manson JE, Hankey GJ, Spence JD, Galan P, Bonaa KH, Jamison R, Gaziano JM, Guarino P, Baron JA, Logan RF, Giovannucci EL, Den Heijer M, Ueland PM, Bennett D, Collins R, Peto R: Effects of folic acid supplementation on overall and site-specific cancer incidence during the randomised trials: meta-analyses of data on 50,000 individuals. Lancet 2013, 381:1029-1036.

65. Goh Yl, Bollano E, Einarson TR, Koren G: Prenatal multivitamin supplementation and rates of pediatric cancers: a meta-analysis. Clin Pharmacol Ther 2007, 81:685-691.

66. French AE, Grant R, Weitzman S, Ray JG, Vermeulen MJ, Sung L, Greenberg $M$, Koren G: Folic acid food fortification is associated with a decline in neuroblastoma. Clin Pharmacol Ther 2003, 74:288-294.

67. Grupp SG, Greenberg ML, Ray JG, Busto U, Lanctot KL, Nulman I, Koren G: Pediatric cancer rates after universal folic acid flour fortification in Ontario. J Clin Pharmacol 2011, 51:60-65.

68. Lonn E, Yusuf S, Arnold MJ, Sheridan P, Pogue J, Micks M, McQueen MJ, Probstfield J, Fodor G, Held C, Genest J Jr: Homocysteine lowering with folic acid and B vitamins in vascular disease. N Engl J Med 2006, 354:1567-1577.

69. Sauer J, Mason JB, Choi SW: Too much folate: a risk factor for cancer and cardiovascular disease? Curr Opin Clin Nutr Metab Care 2009, 12:30-36.

70. Thakur S, Thakur SD, Wani NA, Kaur J: Reduced expression of folate transporters in kidney of a rat model of folate oversupplementation. Genes Nutr 2014, 9:369.

71. Timmermans S, Jaddoe WW, Hofman A, Steegers-Theunissen RP, Steegers EA: Periconception folic acid supplementation, fetal growth and the risks of low birth weight and preterm birth: the Generation R Study. Br J Nutr 2009, 102:777-785.

72. Bukowski R, Malone FD, Porter FT, Nyberg DA, Comstock CH, Hankins GD, Eddleman K, Gross SJ, Dugoff L, Craigo SD, Timor-Tritsch IE, Carr SR, Wolfe HM, D'Alton ME: Preconceptional folate supplementation and the risk of spontaneous preterm birth: a cohort study. PLOS Med 2009, 6:e1000061.

73. Catov JM, Bodnar LM, Olsen J, Olsen S, Nohr EA: Periconceptional multivitamin use and risk of preterm or small-for-gestational-age births in the Danish National Birth Cohort. Am J Clin Nutr 2011, 94:906-912.

74. Catov JM, Nohr EA, Bodnar LM, Knudson VK, Olsen SF, Olsen J: Association of periconceptional multivitamin use with reduced risk of preeclampsia among normal-weight women in the Danish National Birth Cohort. Am J Epidemiol 2009, 169:1304-1311. 
75. Alwan NA, Greenwood DC, Simpson NA, McArdle HJ, Cade JE: The relationship between dietary supplement use in late pregnancy and birth outcomes: a cohort study in British women. BJOG 2010, 117:821-829.

76. Whitrow MJ, Moore VM, Rumbold AR, Davies MJ: Effect of supplemental folic acid in pregnancy on childhood asthma: a prospective birth cohort study. Am J Epidemiol 2009, 170:1486-1493.

77. Haberg SE, London SJ, Stigum H, Nafstad P, Nystad W: Folic acid supplements in pregnancy and early childhood respiratory health. Arch Dis Child 2009, 94:180-184.

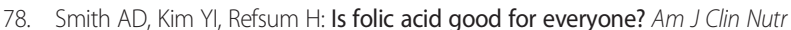
2008, 87:517-533.

79. Kallen B: Use of folic acid supplementation and risk for dizygotic twinning. Early Hum Dev 2004, 80:143-151.

80. Muggli $E E$, Halliday JL: Folic acid and risk of twinning: a systematic review of the recent literature, July 1994 to July 2006. Med J Aust 2007, $186: 243-248$.

81. Berry RJ, Kihlberg R, Devine O: Impact of misclassification of in vitro fertilisation in studies of folic acid and twinning: modelling using population based Swedish vital records. BMJ 2005, 330:815.

82. Vollset SE, Gjessing HK, Tandberg A, Ronning T, Irgens LM, Baste V, Nilsen RM, Daltveit AK: Folate supplementation and twin pregnancies. Epidemiology 2005, 16:201-205.

83. Parker SE, Yazdy MM, Tinker SC, Mitchell AA, Werler MM: The impact of folic acid intake on the association among diabetes mellitus, obesity, and spina bifida. Am J Obstet Gynecol 2013, 209:239.e1-8.

84. Ahrens K, Yazdy MM, Mitchell AA, Werler MM: Folic acid intake and spina bifida in the era of dietary folic acid fortification. Epidemiology 2011, 22:731-737.

85. Cortes F, Mellado C, Pardo RA, Villarroel LA, Hertrampf E: Wheat flour fortification with folic acid: changes in neural tube defects rates in Chile. Am J Med Genet A 2012, 158A:1885-1890.

86. Hosseini MB, Khamnian Z, Dastgiri S, Samadi RB, Ravanshad Y: Folic acid and birth defects: a case study (Iran). J Pregnancy 2011, 2011:370458.

87. Imdad A, Yakoob MY, Bhutta ZA: The effect of folic acid, protein energy and multiple micronutrient supplements in pregnancy on stillbirths. BMC Public Health 2011, 11(Suppl 3):S4.

88. Hollis ND, Allen EG, Oliver TR, Tinker SW, Druschel C, Hobbs CA, O'Leary LA Romitti PA, Royle MH, Torfs CP, Freeman SB, Sherman SL, Bean LJ: Preconception folic acid supplementation and risk for chromosome 21 nondisjunction: a report from the National Down Syndrome Project. Am J Med Genet A 2013, 161A:438-444.

89. Bean LJ, Allen EG, Tinker SW, Hollis ND, Locke AE, Druschel C, Hobbs CA, O'Leary L, Romitti PA, Royle MH, Torfs CP, Dooley KJ, Freeman SB, Sherman SL: Lack of maternal folic acid supplementation is associated with heart defects in Down syndrome: a report from the National Down Syndrome Project. Birth Defects Res A Clin Mol Teratol 2011, 91:885-893.

90. Schmidt RJ, Tancredi DJ, Ozonoff S, Hansen RL, Hartiala J, Allayee H, Schmidt LC, Tassone F, Hertz-Picciotto I: Maternal periconceptional folic acid intake and risk of autism spectrum disorders and developmental delay in the CHARGE (CHildhood Autism Risks from Genetics and Environment) case-control study. Am J Clin Nutr 2012, 96:80-89.

91. Suren P, Roth C, Bresnahan M, Haugen M, Hornig M, Hirtz D, Lie KK, Lipkin WI, Magnus P, Reichborn-Kjennerud T, Schjolberg S, Davey SG, Oyen AS, Susser $\mathrm{E}$, Stoltenberg C: Association between maternal use of folic acid supplements and risk of autism spectrum disorders in children. JAMA 2013, 309:570-577.

92. Roth C, Magnus P, Schjolberg S, Stoltenberg C, Suren P, McKeague IW, Davey SG, Reichborn-Kjennerud T, Susser E: Folic acid supplements in pregnancy and severe language delay in children. JAMA 2011, 306:1566-1573.

93. Chatzi L, Papadopoulou E, Koutra K, Roumeliotaki T, Georgiou V, Stratakis N, Lebentakou V, Karachaliou M, Vassilaki M, Kogevinas M: Effect of high doses of folic acid supplementation in early pregnancy on child neurodevelopment at 18 months of age: the mother-child cohort 'Rhea' study in Crete, Greece. Public Health Nutr 2012, 15:1728-1736.

94. Bedard T, Lowry RB, Sibbald B, Harder JR, Trevenen C, Horobec V, Dyck JD: Folic acid fortification and the birth prevalence of congenital heart defect cases in Alberta, Canada. Birth Defects Res A Clin Mol Teratol 2013, 97:564-570.

95. Li X, Li S, Mu D, Liu Z, Li Y, Lin Y, Chen X, You F, Li N, Deng K, Deng Y, Wang $Y$, Zhu J: The association between periconceptional folic acid supplementation and congenital heart defects: a case-control study in China. Prev Med 2013, 56:385-389.

96. Rozendaal AM, Van Essen AJ, Te Meerman GJ, Bakker MK, van der Biezen J J, Goorhuis-Brouwer SM, Vermeij-Keers C, De Walle HE: Periconceptional folic acid associated with an increased risk of oral clefts relative to non-folate related malformations in the Northern Netherlands: a population based case-control study. Eur J Epidemiol 2013, 28:875-887

97. Vila-Nova C, Wehby GL, Queiros FC, Chakraborty H, Felix TM, Goco N, Moore J Gewehr EV, Lins L, Affonso CM, Murray JC: Periconceptional use of folic acid and risk of miscarriage - findings of the Oral Cleft Prevention Program in Brazil. J Perinat Med 2013, 41:461-466.

98. Wehby GL, Felix TM, Goco N, Richieri-Costa A, Chakraborty H, Souza J, Pereira R, Padovani C, Moretti-Ferreira D, Murray JC: High dosage folic acid supplementation, oral cleft recurrence and fetal growth. Int J Environ Res Public Health 2013, 10:590-605.

99. Kelly D, O'Dowd T, Reulbach U: Use of folic acid supplements and risk of cleft lip and palate in infants: a population-based cohort study. $\mathrm{Br} J \mathrm{Gen}$ Pract 2012, 62:e466-e472.

100. Li S, Chao A, Li Z, Moore CA, Liu Y, Zhu J, Erickson JD, Hao L, Berry RJ: Folic acid use and nonsyndromic orofacial clefts in China: a prospective cohort study. Epidemiology 2012, 23:423-432.

101. Michels AC, Van den Elzen ME, Vles JS, Van der Hulst RR: Positional plagiocephaly and excessive folic Acid intake during pregnancy. Cleft Palate Craniofac J 2012, 49:1-4.

102. Correa A, Gilboa SM, Botto LD, Moore CA, Hobbs CA, Cleves MA, Riehle-Colarusso TJ, Waller DK, Reece EA: Lack of periconceptional vitamins or supplements that contain folic acid and diabetes mellitus-associated birth defects. Am J Obstet Gynecol 2012, 206:218.e1-13.

103. Banhidy F, Dakhlaoui A, Puho EH, Czeizel AA: Is there a reduction of congenital abnormalities in the offspring of diabetic pregnant women after folic acid supplementation? A population-based case-control study. Congenit Anom (Kyoto) 2011, 51:80-86.

104. Hossein-nezhad A, Mirzaei K, Maghbooli Z, Najmafshar A, Larijani B: The influence of folic acid supplementation on maternal and fetal bone turnover. J Bone Miner Metab 2011, 29:186-192.

105. Mantovani E, Filippini F, Bortolus R, Franchi M: Folic acid supplementation and preterm birth: results from observational studies. Biomed Res Int 2014, 2014:481914.

106. Shaw GM, Carmichael SL, Yang W, Siega-Riz AM: Periconceptional intake of folic acid and food folate and risks of preterm delivery. Am J Perinatol 2011, 28:747-752.

107. Byrne J: Periconceptional folic acid prevents miscarriage in Irish families with neural tube defects. Ir J Med Sci 2011, 180:59-62.

108. Li Z, Ye R, Zhang L, Li H, Liu J, Ren A: Folic acid supplementation during early pregnancy and the risk of gestational hypertension and preeclampsia. Hypertension 2013, 61:873-879.

109. Furness D, Fenech M, Dekker G, Khong TY, Roberts C, Hague W: Folate, vitamin B12, vitamin B6 and homocysteine: impact on pregnancy outcome. Matern Child Nutr 2013, 9:155-166.

110. Dwarkanath $P$, Barzilay JR, Thomas T, Thomas A, Bhat S, Kurpad AV: High folate and low vitamin B-12 intakes during pregnancy are associated with smallfor-gestational age infants in South Indian women: a prospective observational cohort study. Am J Clin Nutr 2013, 98:1450-1458.

111. Lassi ZS, Salam RA, Haider BA, Bhutta ZA: Folic acid supplementation during pregnancy for maternal health and pregnancy outcomes. Cochrane Database Syst Rev 2013, 3: CD006896.

112. Furness DL, Yasin N, Dekker GA, Thompson SD, Roberts CT: Maternal red blood cell folate concentration at 10-12 weeks gestation and pregnancy outcome. J Matern Fetal Neonatal Med 2012, 25:1423-1427.

113. Papadopoulou E, Stratakis N, Roumeliotaki T, Sarri K, Merlo DF, Kogevinas M, Chatzi L: The effect of high doses of folic acid and iron supplementation in early-to-mid pregnancy on prematurity and fetal growth retardation: the mother-child cohort study in Crete, Greece (Rhea study). Eur J Nutr 2013, 52:327-336.

114. Fekete K, Berti C, Trovato M, Lohner S, Dullemeijer C, Souverein OW, Cetin I, Decsi T: Effect of folate intake on health outcomes in pregnancy: a systematic review and meta-analysis on birth weight, placental weight and length of gestation. Nutr J 2012, 11:75.

115. Pastor-Valero M, Navarrete-Munoz EM, Rebagliato M, Iniguez C, Murcia M, Marco A, Ballester F, Vioque J: Periconceptional folic acid supplementation 
and anthropometric measures at birth in a cohort of pregnant women in Valencia, Spain. Br J Nutr 2011, 105:1352-1360.

116. Der Woude PA Z-V, De Walle HE, Hoek A, Bos HJ, Boezen HM, Koppelman GH, Den Berg LT DJ-V, Scholtens S: Maternal high-dose folic acid during pregnancy and asthma medication in the offspring. Pharmacoepidemiol Drug Saf 2014

117. Veeranki SP, Gebretsadik T, Dorris SL, Mitchel EF, Hartert TV, Cooper WO, Tylavsky FA, Dupont W, Hartman TJ, Carroll KN: Association of folic acid supplementation during pregnancy and infant bronchiolitis. Am J Epidemiol 2014, 179:938-946.

118. Brown SB, Reeves KW, Bertone-Johnson ER: Maternal folate exposure in pregnancy and childhood asthma and allergy: a systematic review. Nutr Rev 2014, 72:55-64.

119. Crider KS, Cordero AM, Qi YP, Mulinare J, Dowling NF, Berry RJ: Prenatal folic acid and risk of asthma in children: a systematic review and meta-analysis. Am J Clin Nutr 2013, 98:1272-1281.

120. Bekkers MB, Elstgeest LE, Scholtens S, Haveman-Nies A, De Jongste JC, Kerkhof M, Koppelman GH, Gehring U, Smit HA, Wijga AH: Maternal use of folic acid supplements during pregnancy, and childhood respiratory health and atopy. Eur Respir J 2012, 39:1468-1474.

121. Kiefte-de Jong JC, Timmermans S, Jaddoe WW, Hofman A, Tiemeier H, Steegers EA, De Jongste JC, Moll HA: High circulating folate and vitamin B-12 concentrations in women during pregnancy are associated with increased prevalence of atopic dermatitis in their offspring. J Nutr 2012, 142:731-738.

122. Dunstan JA, West C, McCarthy S, Metcalfe J, Meldrum S, Oddy WH, Tulic MK, D'Vaz N, Prescott SL: The relationship between maternal folate status in pregnancy, cord blood folate levels, and allergic outcomes in early childhood. Allergy 2012, 67:50-57.

123. Martinussen MP, Risnes KR, Jacobsen GW, Bracken MB: Folic acid supplementation in early pregnancy and asthma in children aged 6 years. Am J Obstet Gynecol 2012, 206:72-77.

124. Magdelijns FJ, Mommers M, Penders J, Smits L, Thijs C: Folic acid use in pregnancy and the development of atopy, asthma, and lung function in childhood. Pediatrics 2011, 128:e135-e144.

125. Sharland E, Montgomery B, Granell R: Folic acid in pregnancy - is there a link with childhood asthma or wheeze? Aust Fam Physician 2011 40:421-424

126. Haberg SE, London SJ, Nafstad P, Nilsen RM, Ueland PM, Vollset SE, Nystad W: Maternal folate levels in pregnancy and asthma in children at age 3 years. J Allergy Clin Immunol 2011, 127:262-264.

127. McNulty B, McNulty H, Marshall B, Ward M, Molloy AM, Scott JM, Dornan J, Pentieva K: Impact of continuing folic acid after the first trimester of pregnancy: findings of a randomized trial of Folic Acid Supplementation in the Second and Third Trimesters. Am J Clin Nutr 2013, 98:92-98.

128. Hoyo C, Murtha AP, Schildkraut JM, Jirtle RL, Demark-Wahnefried W, Forman MR, Iversen ES, Kurtzberg J, Overcash F, Huang Z, Murphy SK: Methylation variation at IGF2 differentially methylated regions and maternal folic acid use before and during pregnancy. Epigenetics 2011, 6:928-936.

129. Greenop KR, Miller M, De Klerk NH, Scott RJ, Attia J, Ashton LJ, Dalla-Pozza L, Bower C, Armstrong BK, Milne E: Maternal dietary intake of folate and vitamins b6 and B12 during pregnancy and risk of childhood brain tumors. Nutr Cancer 2014, 66:800-809.

130. Chokkalingam AP, Chun DS, Noonan EJ, Pfeiffer CM, Zhang M, Month SR, Taggart DR, Wiemels JL, Metayer C, Buffler PA: Blood levels of folate at birth and risk of childhood leukemia. Cancer Epidemiol Biomarkers Prev 2013, 22:1088-1094.

131. Orjuela MA, Cabrera-Munoz L, Paul L, Ramirez-Ortiz MA, Liu X, Chen J, Mejia-Rodriguez F, Medina-Sanson A, Diaz-Carreno S, Suen IH, Selhub J, Ponce-Castaneda MV: Risk of retinoblastoma is associated with a maternal polymorphism in dihydrofolatereductase (DHFR) and prenatal folic acid intake. Cancer 2012, 118:5912-5919.

132. Milne E, Greenop KR, Bower C, Miller M, Van Bockxmeer FM, Scott RJ, De Klerk NH, Ashton LJ, Gottardo NG, Armstrong BK: Maternal use of folic acid and other supplements and risk of childhood brain tumors. Cancer Epidemiol Biomarkers Prev 2012, 21:1933-1941.

133. Amigou A, Rudant J, Orsi L, Goujon-Bellec S, Leverger G, Baruchel A, Bertrand Y, Nelken B, Plat G, Michel G, Haouy S, Chastagner P, Ducassou S, Rialland X, Hemon D, Clavel J: Folic acid supplementation, MTHFR and MTRR polymorphisms, and the risk of childhood leukemia: the ESCALE study (SFCE). Cancer Causes Control 2012, 23:1265-1277.
134. Linabery AM, Johnson KJ, Ross JA: Childhood cancer incidence trends in association with US folic acid fortification (1986-2008). Pediatrics 2012 129:1125-1133.

135. Crider KS, Bailey LB, Berry RJ: Folic acid food fortification-its history, effect, concerns, and future directions. Nutrients 2011, 3:370-384.

136. EFSA meeting summary report: Folic Acid: An Update on Scientific Developments 2009. http://www.efsa.europa.eu/en/home/publication/ efsafolicacid.pdf. Ref Type: Report

137. The Kimmel Institute: 2014. http://www.thekimmelinstitute.com/varicoseveins-pregnancy/.

138. The Johns Hopkins University: 2014. http://www.hopkinsmedicine.org/ healthlibrary/test_procedures/gynecology/external_and_internal_heart_ rate_monitoring_of_the_fetus_92,P07776/.

doi:10.1186/s12929-014-0077-z

Cite this article as: Barua et al: Folic acid supplementation in pregnancy and implications in health and disease. Journal of Biomedical Science $201421: 77$.

\section{Submit your next manuscript to BioMed Central and take full advantage of:}

- Convenient online submission

- Thorough peer review

- No space constraints or color figure charges

- Immediate publication on acceptance

- Inclusion in PubMed, CAS, Scopus and Google Scholar

- Research which is freely available for redistribution 